\title{
Targeting groundwater potential zones using Electrical resistivity and GIS techniques in Kadavanar Sub-basin, South India
}

\section{Karunanidhi " ", M. Suresh ${ }^{\text {b }}$, T. Subramani ', B. Anand ${ }^{\text {a }}$}

${ }^{a}$ Department of Civil Engineering, Sri Shakthi Institute of Engineering and Technology, Coimbatore641062, Tamil Nadu, India.

${ }^{b}$ Department of Civil Engineering, Jayalakshmi Institute of Technology, Thoppur, Dharmapuri- 636352, Tamil Nadu, India.

'Department of Geology, CEG, Anna University, Chennai - 600025, Tamil Nadu, India.

* Corresponding Author: karunasamygis@gmail.com

Received: $5^{\text {th }}$ July 2020 , Accepted: $16^{\text {th }}$ October 2020

Abstract: Geographical Information System techniques are widely used to determine suitable sites for groundwater recharge through artificial recharge techniques. The present research work is to identify suitable locations for constructing artificial recharge structures in the Kadavanar Sub-basin, South India. People in the Sub-basin mainly depend on the groundwater resources for drinking and irrigation purposes. Groundwater resources are often overexploited in many parts of this Sub-basin to meet the water demand leading to groundwater consumption. A lot of surfaces and sub-surface information and criteria are required for mapping the groundwater recharge zone. This is where the geographic information system [GIS] provides the right impetus besides the groundwater prospective zone to harness multilayered spatial data so that multicriteria analysis is possible. This analysis integrates historic rainfall data analysis, groundwater level fluctuation, stream network, aquifer thickness, land use/land cover and basin slope. Drainage map, slope map and land use/land cover maps were prepared from satellite imageries. Vertical electrical sounding (VES) geophysical survey with Schlumberger electrode configuration was also conducted in the basin at 50 locations to map the aquifer thickness. Spatial variation maps for groundwater level and aquifer thickness were generated using GIS. Weighted aggregation method was used in this study to obtain groundwater recharge maps. Finally, multicriteria analysis has been carried out to identify and assess the potential sites for groundwater recharge according to the associated weightages. It is established that GIS is best suited for the mapping of groundwater recharge zones. A similar study can be extended to any other hard-rock region facing water crises. 
Keywords: Vertical electrical sounding (VES), Spatial variation of water level, Geographic Information System (GIS), Multi-criteria analysis, Groundwater recharge sites, Kadavanar Subbasin.

\section{Introduction}

Groundwater serves as the primary source for drinking, other domestic uses, irrigation and industrial purposes in India [1]. Despite of receiving high monsoon rainfall, there is acute water scarcity in various parts of the country due to improper water conservation [2]. A major part of the rainfall is wasted through overflow causing the lowering of water table. Sustainable management of groundwater through artificial recharge techniques has been implemented by a few researchers [3]. These researches show that in different regions of the world artificial recharge techniques can be applied successfully to recharge the groundwater [4, 5]. For the artificial groundwater recharge site selection, it is very important to conduct a detailed study on the geology, topography, structural features, and soil and drainage density to provide explicit details about that area [6].

Lately, multi-criteria analysis methods have been used by researchers to identify potential groundwater recharge zones through various artificial recharge techniques [5, 7, 8]. Remote Sensing (RS) and Geographical Information System (GIS) techniques can be used to identify suitable sites for artificial recharge structures [2, 9-12]. A set of weights for the different themes are decided based on distinctive judgment, considering their relative significance from the artificial recharge view point. These thematic layers can be integrated into a GIS environment to determine potential areas for artificial recharge.

\section{Study Area}

The study area Kadavanar Sub-basin is located in Dindigul and Karur districts of Tamil Nadu, India which occupies an area of $2254.65 \mathrm{~km}^{2}$. There is a plain area of $1857.58 \mathrm{~km}^{2}$ and Hill and forest covers an area of about $397.07 \mathrm{~km}^{2}$ (Figure 1). The study area is bounded by Madurai district in the south, Theni district in the northwest, Sivaganga in the Southeast, Thiruchirapalli in the West, Namakkal in the north and Erode on the northwest side. The Kadavanar Sub-basin lies between latitudes N 10 $09^{\prime} 56.70^{\prime}$ and $10^{\circ} 52^{\prime} 31.5^{\prime}$, longitudes E $77^{\circ} 37^{\prime} 29.29^{\prime \prime}$ and $78^{\circ} 13^{\prime} 14.21$ ". Groundwater recharge in the study area is mainly because of the monsoon rainfall. The average rainfall in this area is $838.96 \mathrm{~mm}$. The geology of the study area reveals that the area is underlain by crystalline rocks of Archaean age. The weathered and fractured rocks act as potential zones for groundwater recharge. Interconnected fractures in crystalline rocks play an important role in fluid flow in hard rock terrain. This secondary porosity and permeability of the hard rock will allow groundwater flow and accumulation. As the study area is hard rock terrain, resistivity surveys were conducted only in locations where the ground surface is suitable for laying the electrode array. Hence, the entire area could not be mapped. 


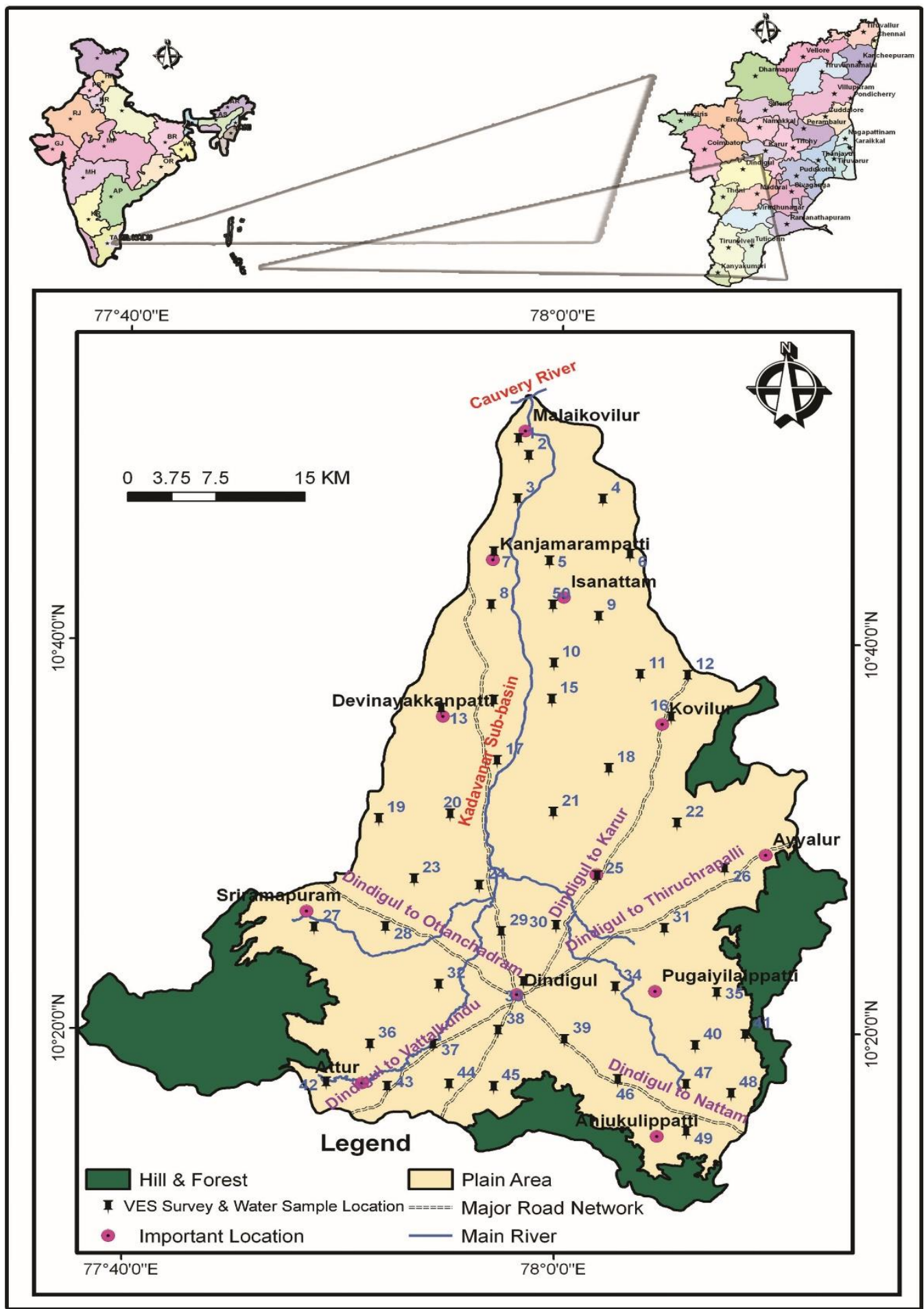

Figure. 1 Geophysical Survey Location with Study Area Map 


\section{Materials and Methods}

In a hard rock terrain with arid climate, the primary work is to identify the resource to replenish the groundwater. Advancement in technology and with help of ArcGIS 10.1 version software it is most useful for a planner in decision-making to locate the artificial recharge zones. The base map is prepared from Surveys of India (SOI) topo sheets (no. 58 F/11, 13, 14, 15, 16, 58J/1, 2, 3 and 4) of 1:50,000 scale. Geology maps were collected from the geological survey of India. Further, this map analyzed in GIS environment to extract the study area geology. Remote sensing data is very useful for groundwater studies as well as groundwater development and management studies. Using this technology and with help of GIS different thematic maps were generated. Rainfall and water level data were collected from public work department. This data was interpreted average annual rainfall spatial distribution to the Kadavanar Sub-basin. Drainage, surface geology, aquifer thickness, slope map, land use/land cover map and groundwater quality spatial distribution maps were prepared through GIS software. These maps were used for selecting suitable artificial recharge sites. The drainage map was prepared from the Survey of India (SOI) topo sheets. The drainage pattern of the study area is the mostly dendritic, subdendritic and parallel type. The land use classification adopted in the present study was based on National Remote Sensing Agency classification (1996). The slope map of the study area was prepared by GIS software. The spot height data was also used for the preparation of the slope map. Fifty vertical electrical soundings (VES) using Schlumberger configuration with $150 \mathrm{~m}$ spreading were carried out. The locations of these VES are shown in Figure 1. The VES data was first interpreted using the curve matching technique by using IPI2WIN software, and the subsurface layers were delineated. Eventually, the best possible stream locations for the construction of subsurface dykes and check dams for artificial recharge of groundwater were identified through Weighted Index Overlay Analysis (WIOA) using GIS. This analysis combines the multi-class maps. The efficacy of this method lies is the human judgment and it can be incorporated in the analysis. A weight represents the relevant importance of a parameter vis-a-vis the objective [11]. WIOA method is based on the relative importance of the parameters and the classes belonging to each parameter.

\section{Results and Discussion}

\subsection{Geology}

The geological setting of the study area (Figure 2 and Table 1) is underlined by hard rock namely pink migmatite, hornblende-biotite-gneiss, charnockite, quartzite, anorthosite, calcgneiss/limestone, garnet-sillimanite gneiss, granitic gneiss, magnetite quartzite, granite and pyroxene granulite. The basin area is mainly comprised of Pink Migmatite (42.89\%) and Hornblende Biotite Gneiss (29.29\%). The hilly area consists of charnockite rock which demarcates the drainage boundary. The major portion is encompassed by metamorphic crystalline rocks, which are highly folded, fractured and jointed. Quartzite and pyroxene granulite occur in patches, which strike in NW-SE direction. Usually, enormous ruptured lithological 
basement complex setting has little influence on groundwater availability except in cases with secondary porosity through the development of eroded overburden and fractured bedrock units, which form potential groundwater zones. Therefore, appropriate weights are allocated to various rock types present in the study area based on the existence of weathered regolith and fracture systems.

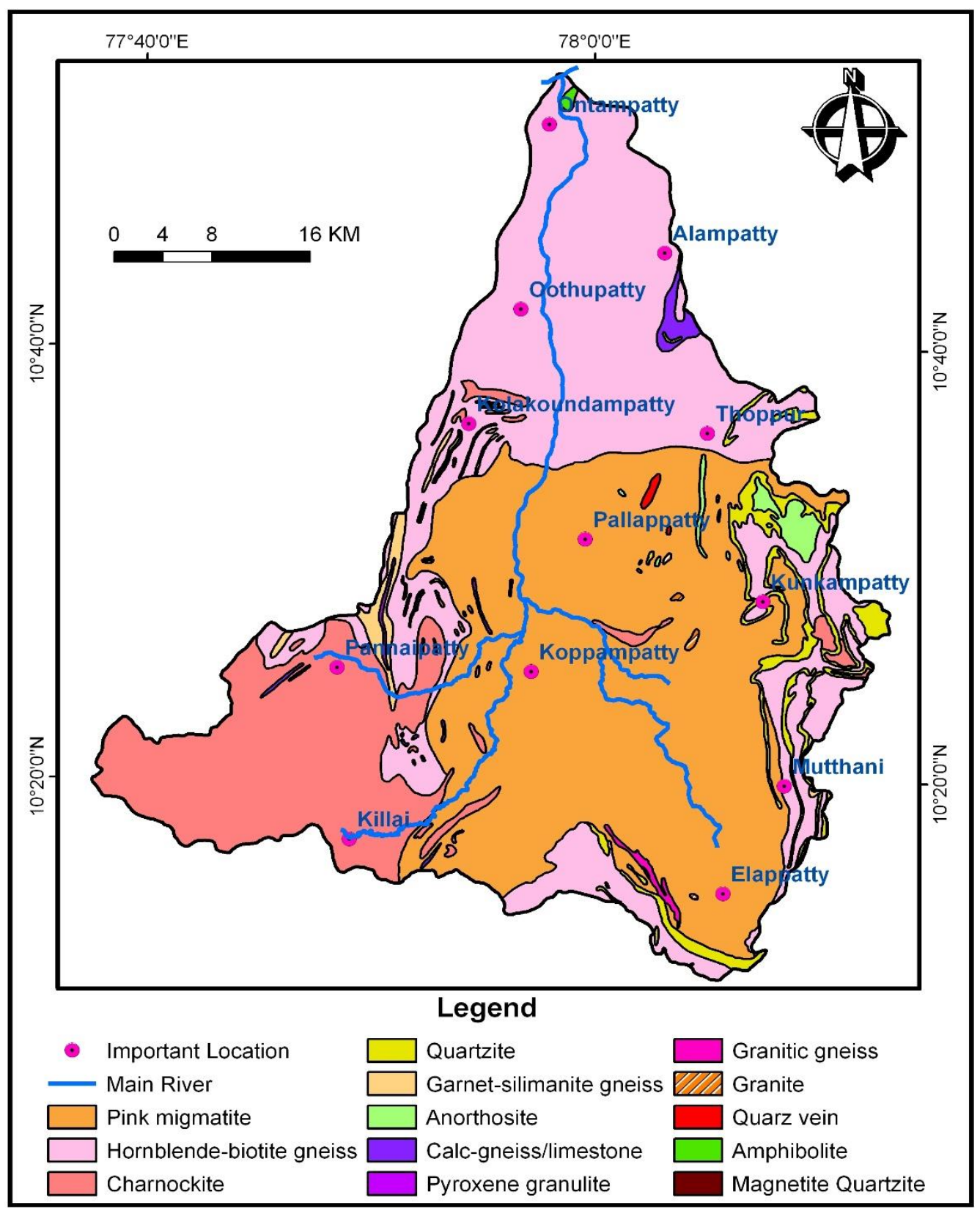

Figure 2 Geology of the Study Area 
Table 1. Geology of the study area - spatial distribution result

\begin{tabular}{|c|c|c|}
\hline Sl.No. & Geology & Area in $\mathrm{Km}^{2}$ \\
\hline 1 & Charnockite & 372.28 \\
\hline 2 & Anorthosite & 19.27 \\
\hline 3 & Magnetite Quartzite & 0.36 \\
\hline 4 & Pyroxene granulite & 5.79 \\
\hline 5 & Calc-gneiss/limestone & 12.49 \\
\hline 6 & Quartzite & 78.50 \\
\hline 7 & Garnet-silimanite gneiss & 22.06 \\
\hline 8 & Amphibolite & 1.81 \\
\hline 9 & Granitic gneiss & 5.09 \\
\hline 10 & Pink migmatite & 975.98 \\
\hline 11 & Hornblende-biotite gneiss & 756.81 \\
\hline 12 & Granite & 2.16 \\
\hline 13 & Quartz vein & 2.05 \\
\hline
\end{tabular}

Table 2. Geological Sequence of Kadavanar Sub-basin

\begin{tabular}{|c|l|l|}
\hline AGE & & \multicolumn{1}{c|}{ Lithology } \\
\hline Quarternary & \multicolumn{1}{|c|}{ Recent to subrecent } & $\begin{array}{l}\text { Kankar } \\
\text { Laterite }\end{array}$ \\
\hline Archaean & - Pegmatites & - Pegmatites and quartz veins \\
\hline & - Granites & $\begin{array}{l}\text { - Pink granites, hornblende - } \\
\text { - Biotite granites and gneisses. }\end{array}$ \\
\hline & - Charnockites & - Acid to basic Charnockites. \\
\hline & - Khondalite & $\begin{array}{l}\text { - Garnet quartz - Feldspar gneiss } \\
\text { - Sillimanite and cordierite Bearing garnetiferous } \\
\text { Gneisses } \\
\end{array}$ \\
& $\begin{array}{l}\text { - Calc gneiss and Limestone } \\
\text { - Quartzite }\end{array}$ \\
\hline
\end{tabular}

The stratigraphic sequences of geological formations have been shown in Table 2, and the characteristic features of individual lithologic units are as follows: Major portion of the study area underlying by pink migmatite followed by hornblende-biotite-gneiss, charnockite rock, Quartzite, Anorthosite, Calc-gneiss/limestone, Garnet-silimanite gneiss, Granitic gneiss, Quartz vein, Granite and Amphibolite etc. 


\subsection{Rainfall}

The ten-year rainfall data (2005-2014) are calculated in ten rain gauge stations at Kodaikanal, Dindigul, Oddanchatram, Palani, Andipatti, Nattam, Palayam, Arachalur, Kodumudi and Puncanbadi in and around the study area. Examination of historical rainfall records of the rain gauge stations in and around the region indicates considerable variation in the distribution of annual rainfall. The data furnished to indicate that the variability of rainfall during the northeast monsoon is considerably higher at all the stations when compared to the southwest monsoon. It is also observed that the variability of annual rainfall is the lowest at Sriramapuram among all the stations analyzed.

For the study of occurrence of drought in the region, the departures of yearly rainfall from normal rainfall for 2005-2014 have been studied in the Kadavanar sub-basin rain gauge stations. Average annual rainfall co-efficient spatial distribution map (Figure 3).

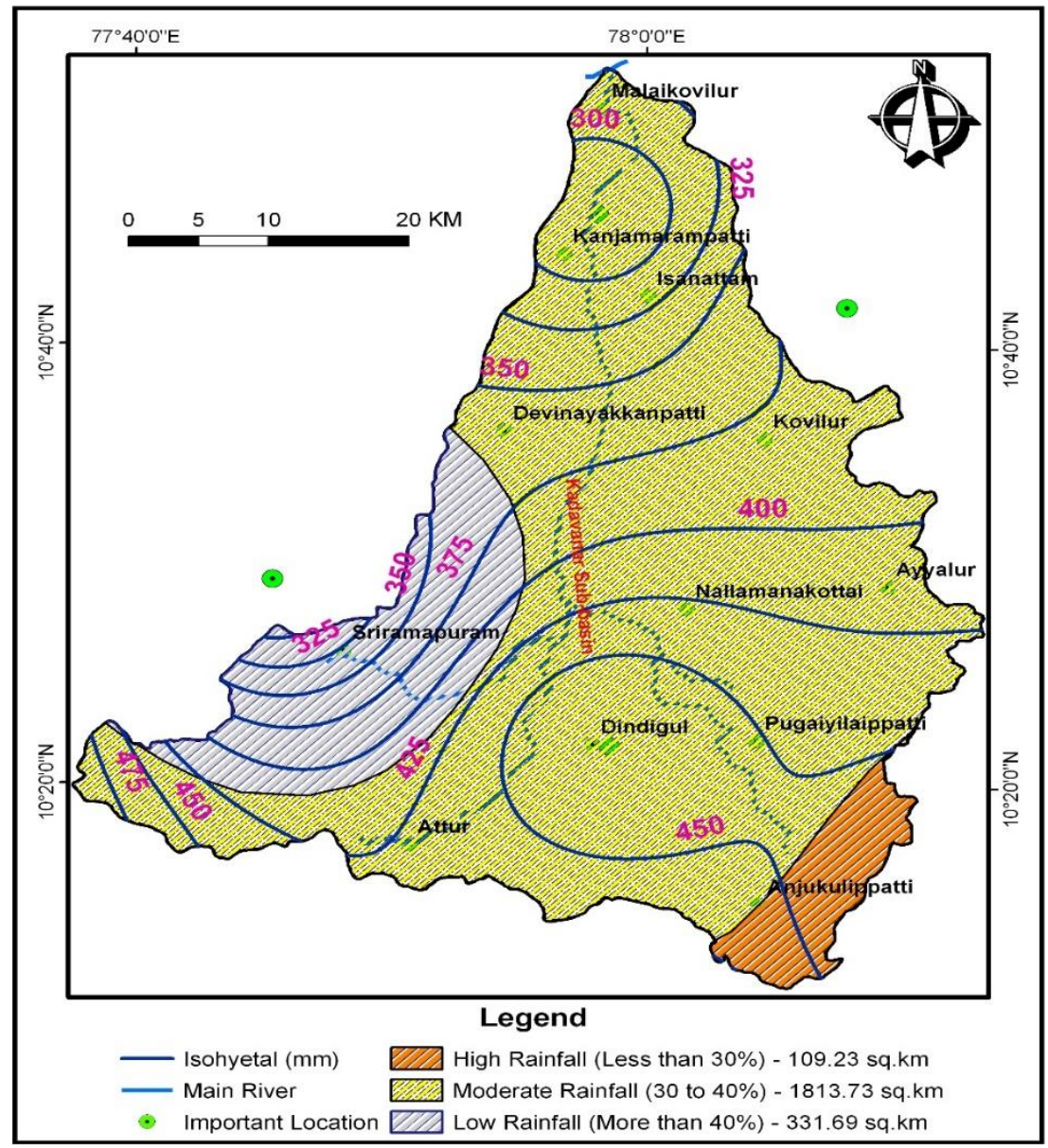

Figure 3 Annual Average Rainfall Isohyetal contour with Co-efficient of variation Spatial Distribution Map 
A study of the negative departures of the annual rainfall from the normal reveals that the probability of occurrence of moderate drought is about $30 \%$. Severe drought conditions were experienced during $0 \%$ of the year. Acute drought conditions were experienced during $20 \%$ of the years. Overall, the total drought year over the region is about $30 \%$.

\subsection{Drainage}

A drainage system is an external expression of the topography of that area and the types and attitude of the subsurface rock. Drainage patterns, varies from one area to the other based on the lithology and structure of a region. A drainage pattern in an area is determined by the distribution and attitude of the surface rocks, arrangements of zones or lines of weakness, etc. No natural resource survey is complete without an analysis of the drainage characteristics of the area. The study area has the dendritic, sub-dendritic and parallel type of drainage (Figure 4).

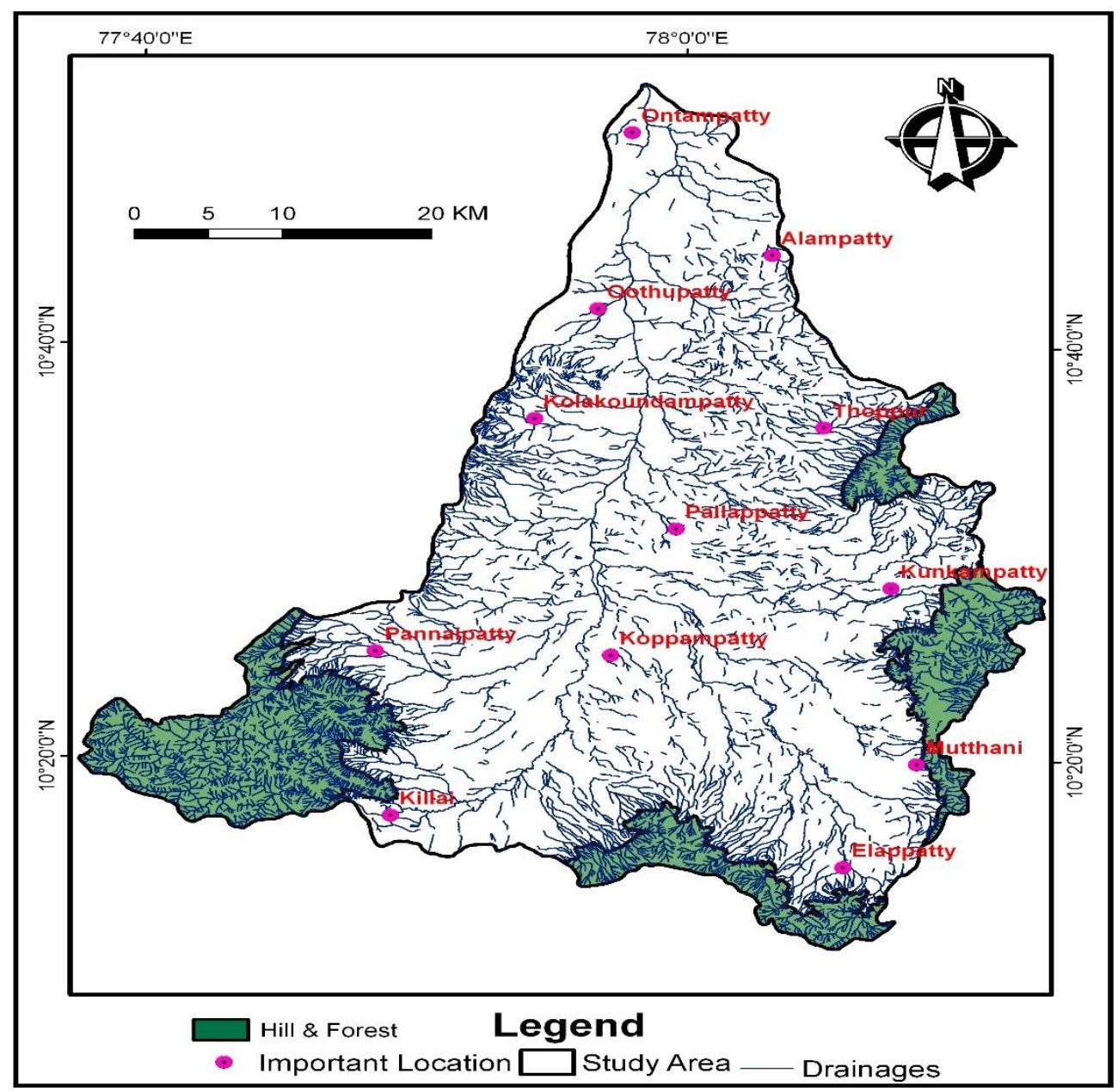

Figure 4. Drainage map of study area 


\subsection{Groundwater Level}

The average annual groundwater level distribution map (Figure 5) reveals that shallow depth of groundwater covers an area of $50.15 \mathrm{~km}^{2}$. Spatially, the small portion of the Sub-basin falls under the good category with respect to the depth of groundwater. Therefore, it is necessary to recharge the groundwater by artificial techniques.

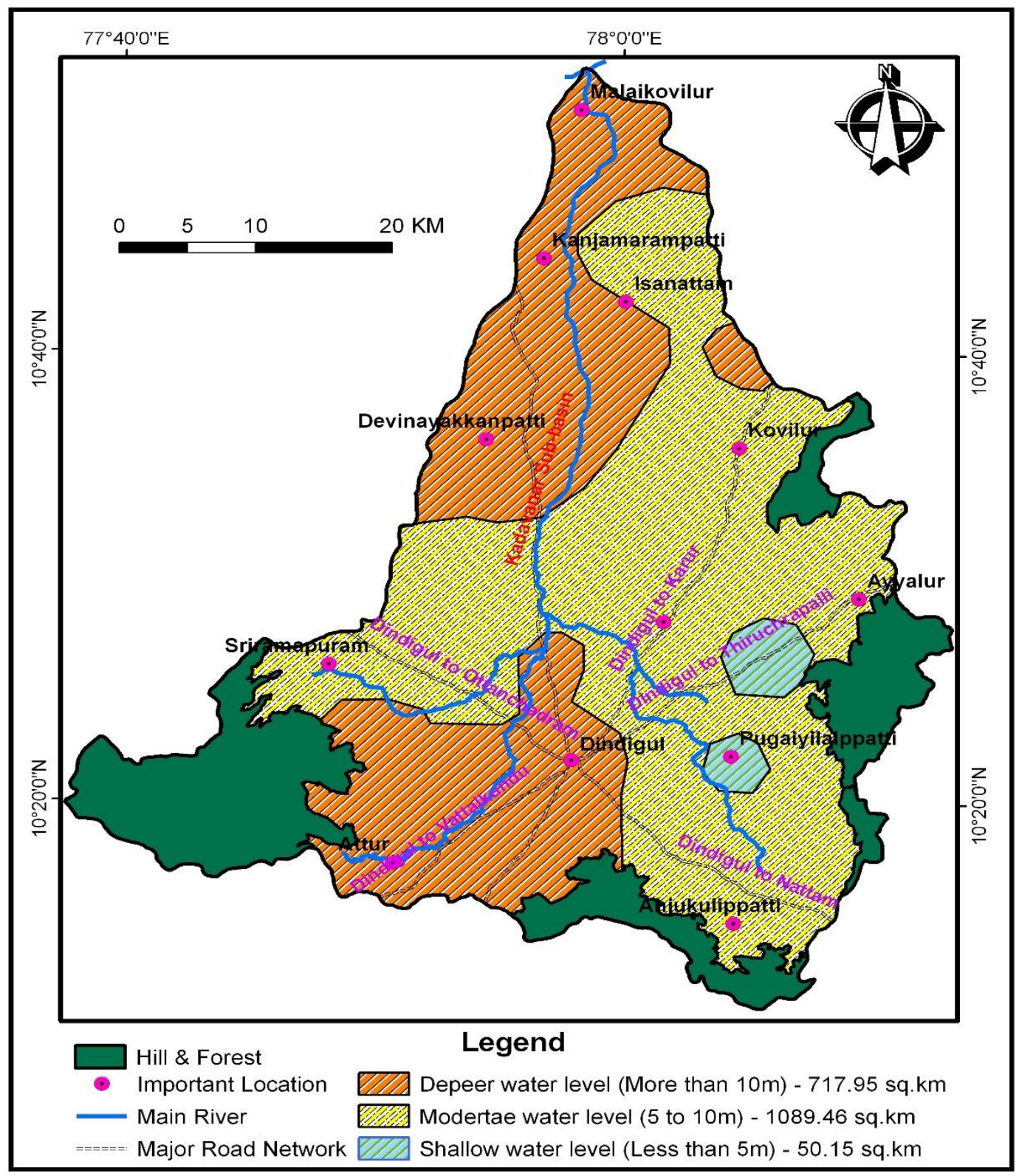

Figure 5 Annual average water level - Spatial Distribution Map 


\subsection{Aquifer thickness}

Aquifer thickness spatial distribution map (Figure 6) was prepared by using GIS based on the geophysical data. The spatial distribution results are presented in the Table 3. Aquifer thickness was classified into three classes, such as Low Thickness, Moderate Thickness and High Thickness. The best groundwater refill zones are indicated by high thickness and moderate thickness zones. High thickness zones cover an area of $341.22 \mathrm{~km}^{2}$.

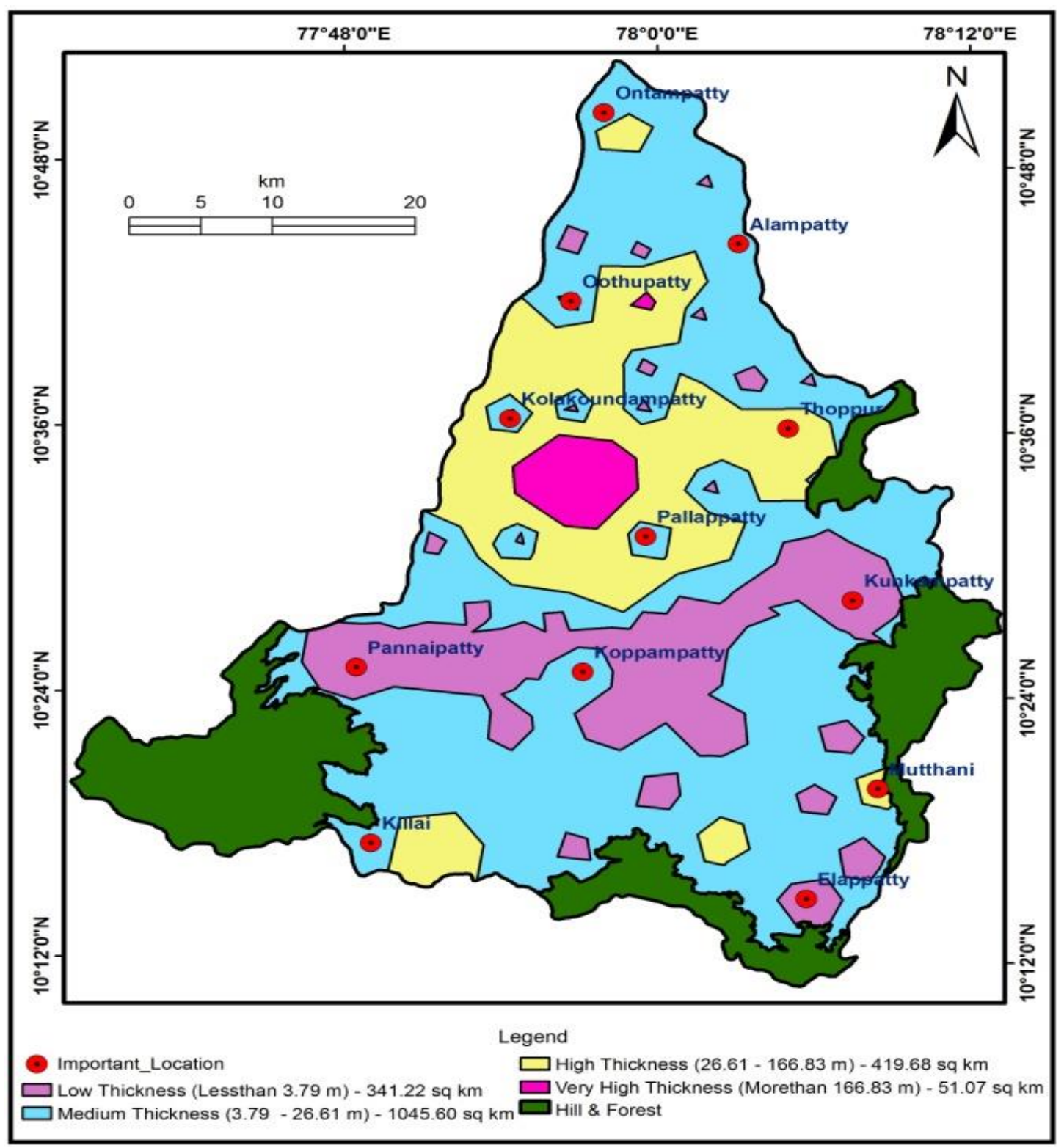

Figure 6 Aquifer Thickness map of the study area 
Table 3 Results of GIS Spatial Distribution-Second Fracture Zone Thickness

\begin{tabular}{|c|c|c|c|}
\hline Class & AquiferThickness (m) & Area in $\mathbf{K m}^{2}$ & Area in Percentage \\
\hline Low thickness & Less than 26.61 & $1386.82 \mathrm{~km}^{2}$ & 74.66 \\
\hline Medium thickness & 26.61 to 166.83 & $419.68 \mathrm{~km}^{2}$ & 22.59 \\
\hline High thickness & More than 166.83 & $51.07 \mathrm{~km}^{2}$ & 2.75 \\
\hline
\end{tabular}

\subsection{Land use/land cover}

The land use/land cover of the study area is characterized by a mixture of forest cover, agricultural activities and land with scrub and land without scrub (waste land) besides water body, river and built-up land (Figure 7).

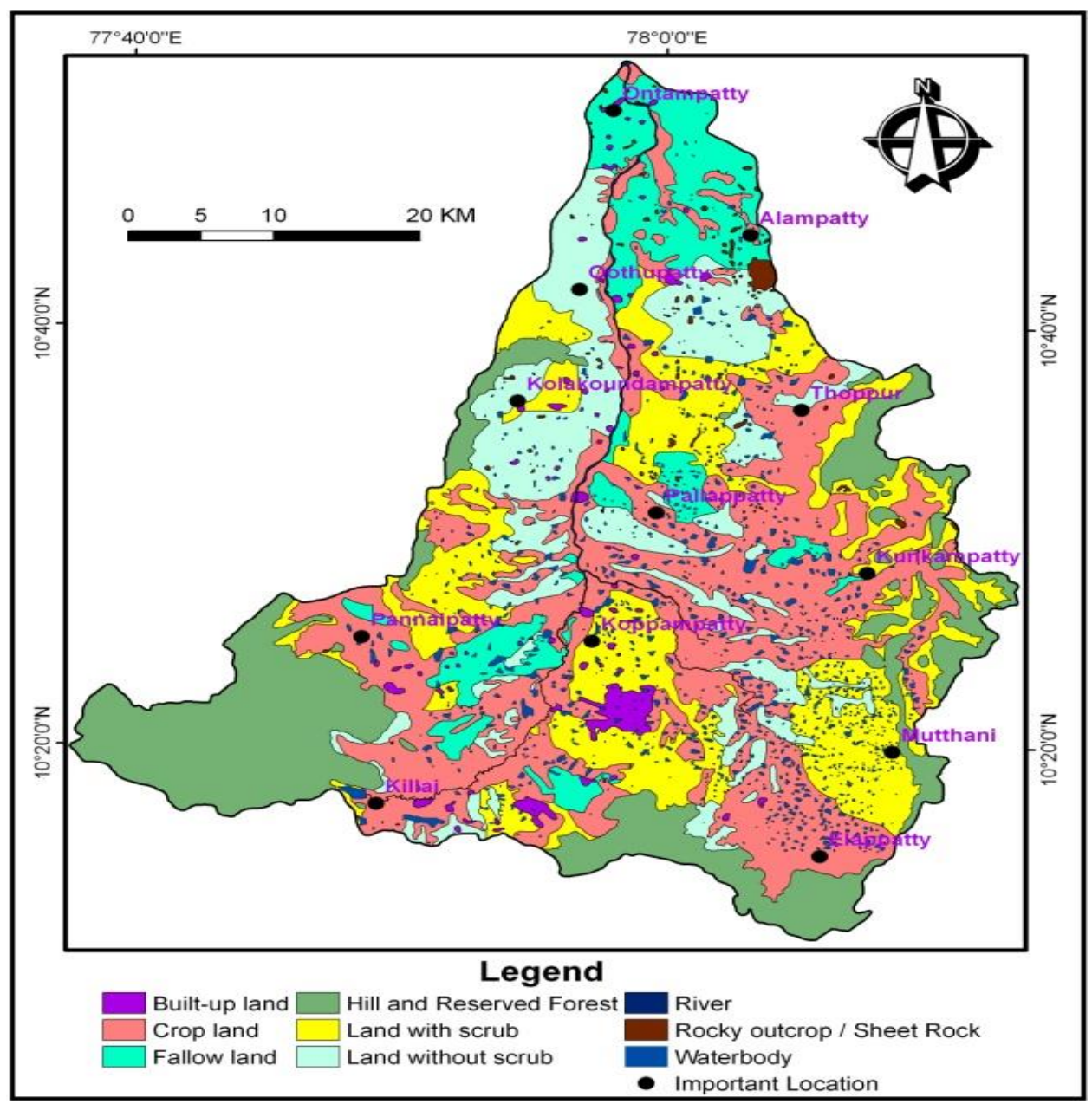

Figure 7 Land use/Land covers Map 
These are readily interpretable from the satellite images. Water bodies are ubiquitously distributed in the study area and cover an area of $59.39 \mathrm{~km}^{2}$. Most of the study area is covered with crop lands and the fallow land of $702.23 \mathrm{~km}^{2}$ and $216.14 \mathrm{~km}^{2}$ respectively are ubiquitously distributed. The residential area is ubiquitously distributed in the entire Sub-basin, and it is about $3236 \mathrm{~km}^{2}$. It lands with scrub and land without scrub area measured about $462.94 \mathrm{~km}^{2}$ and 330.66 $\mathrm{km}^{2}$ respectively. The detailed spatial distribution of land use/land cover classes based on GIS interpretation is presented in the Table 4. The image interpretation study indicates that crop lands are randomly found in the satellite imagery. Dry crop lands are also demarcated based on the tonal variation. The crop land occupies an area of $702.23 \mathrm{~km}^{2}$.

Table 4. GIS Results - Land Use and Land Cover

\begin{tabular}{|c|c|c|}
\hline Sl.No. & Land use and land cover & Area in $\mathbf{~ m}^{2}$ \\
\hline 1 & Built-up land & 32.34 \\
\hline 2 & Crop land & 702.23 \\
\hline 3 & Fallow land & 216.14 \\
\hline 4 & Land with scrub & 462.94 \\
\hline 5 & Land without scrub & 330.66 \\
\hline 6 & Hill and Reserved Forest & 430.51 \\
\hline 7 & River & 8.68 \\
\hline 8 & Rocky outcrop / Sheet Rock & 11.77 \\
\hline 9 & Water body & 59.39 \\
\hline
\end{tabular}

\subsection{Slope}

The slope map of the study area was prepared by adopting the widely used Wentworth's average slope method. The spot heights used in this map were taken from the Survey of India (SOI) top sheets. The various slope classes are shown in (Table 5) and their spatial distribution results are in Figure.8. Fewer degrees of the slope are considered as suitable for artificial recharge of groundwater. For the construction of sub-surface dykes and check dams, less than $10^{\circ}$ of the slope is most favourable.

Table 5. GIS Results - Slope

\begin{tabular}{|c|c|}
\hline Slope in Degree & Area in $\mathbf{K m}^{2}$ \\
\hline $0-5^{\circ}$ & 1903.51 \\
\hline $5-10^{\circ}$ & 238.27 \\
\hline $10-15^{\circ}$ & 86.82 \\
\hline $15-20^{\circ}$ & 21.88 \\
\hline $20-25^{\circ}$ & 4.16 \\
\hline
\end{tabular}




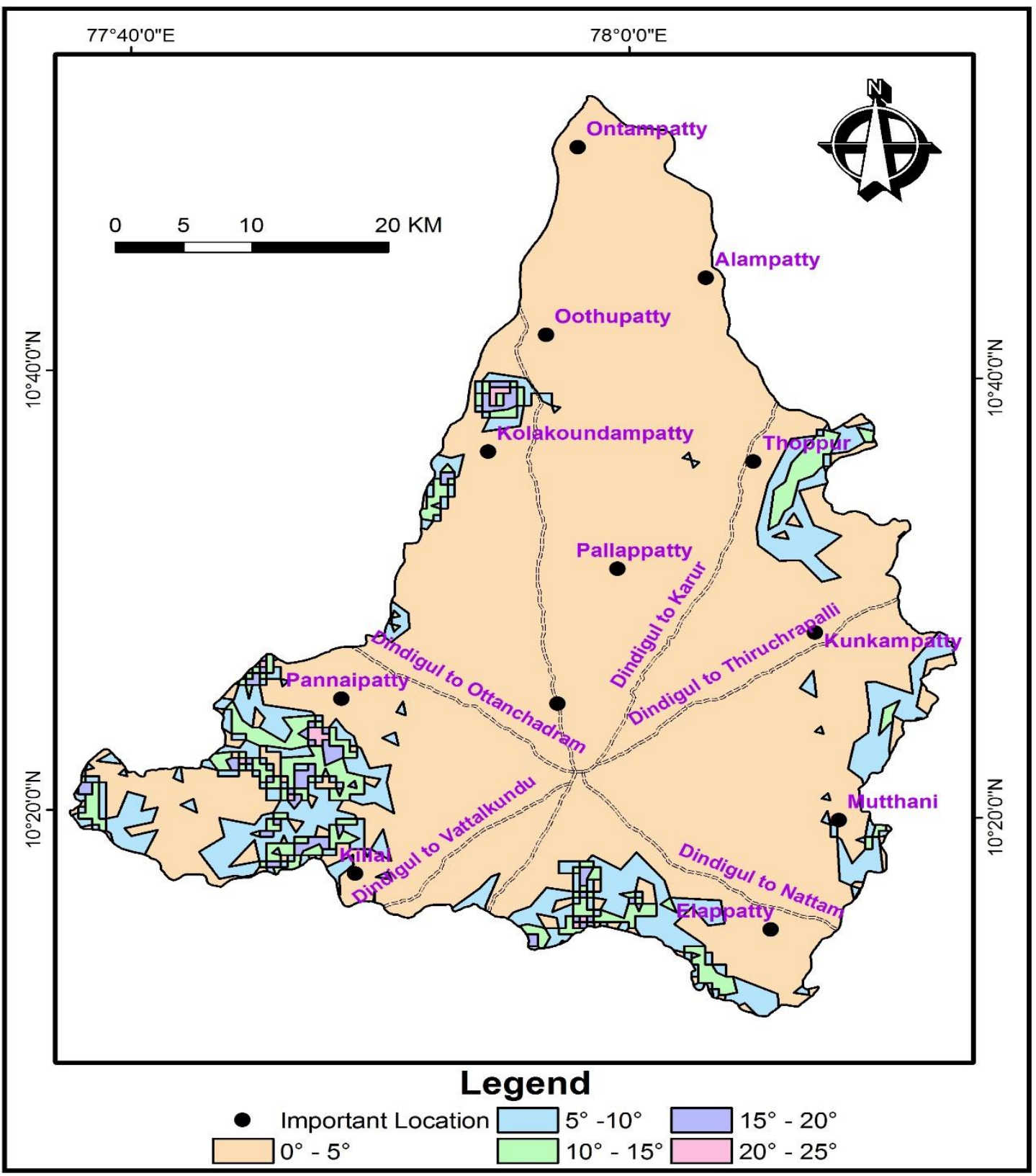

Figure 8 Slope map of the study area

\subsection{Site selection for subsurface dykes}

To arrest the subsurface flow of the water, dyke could be constructed on a stream. The construction of dyke helps to exploit the groundwater during the summer season. The dyke should not be constructed on the very deep bedrock. Site selection criteria and required maps for subsurface dyke method are given below: 
- Drainage,

- Slope (low to moderate),

- Water table (medium to high),

- Aquifer thickness (more topsoil in the upstream side) and

- Depth to bed rock and

The assigned weightage index to demarcate the most favorable area for subsurface dyke construction is given in Table 6. Overlay analysis (Table 7) was carried out based on the above said criteria and thematic maps. GIS output overlaid on the village map is given in Table 7 and Figure 9.

Table 6. Assigned weightages for GIS analysis for subsurface dyke

\begin{tabular}{|c|c|c|c|c|}
\hline \multirow{2}{*}{ Sl. No. } & \multirow{2}{*}{ Criteria } & \multicolumn{3}{|c|}{ Classes } \\
\cline { 3 - 5 } & Poor & Medium & Good \\
\hline 2 & Water level & $\begin{array}{c}1 \\
(>10 \mathrm{~m})\end{array}$ & $\begin{array}{c}\mid c \\
(5-10 \mathrm{~m})\end{array}$ \\
\hline 3 & Aquifer thickness & 1 & 2 & 3 \\
$(<26.61 \mathrm{~m})$ & $(26.61 \mathrm{~m}-166.83 \mathrm{~m})$ & $(>166.83 \mathrm{~m})$ \\
\hline 4 & Slope & 0 & 0 & 2 \\
$\left(0^{\circ}-5^{\circ}\right)$
\end{tabular}

Table 7. GIS Overlay analysis - Subsurface dyke

\begin{tabular}{|c|c|c|c|c|}
\hline Sl. No. & \multicolumn{2}{|c|}{ Maps used } & $\begin{array}{c}\text { GIS Analysis - } \\
\text { Operation }\end{array}$ & Result Map \\
\hline 1 & Aquifer thickness & Water level & Union & Map - 1 \\
\hline 2 & Map - 1 & Aquifer thickness & Union & Map - 2 \\
\hline 3 & Map - 2 & Slope (0-5 ${ }^{\circ}$ & Union & Map - 3 \\
\hline 4 & Map - 3 & Drainage & Intersect & Final map \\
\hline
\end{tabular}

In the present study, weighted indexing method has been used to demarcate the suitability zones for subsurface dyke construction to augment the groundwater resources. In the weighted index overlay, the individual thematic layers and also their classes are assigned weightage (Table 8) based on their relative contribution to the output. The GIS based output is illustrated in Figure 8 and Table 8. The classes with higher values indicate high favorable zones for artificial recharge structures. It is identified that about 20 stream locations are suitable for 
construction of subsurface dykes for artificial recharge. About 540 out of 2740 stream locations are most suitable, and the rests of 2180 locations are moderately suitable for construction of subsurface dykes in the Sub-basin.

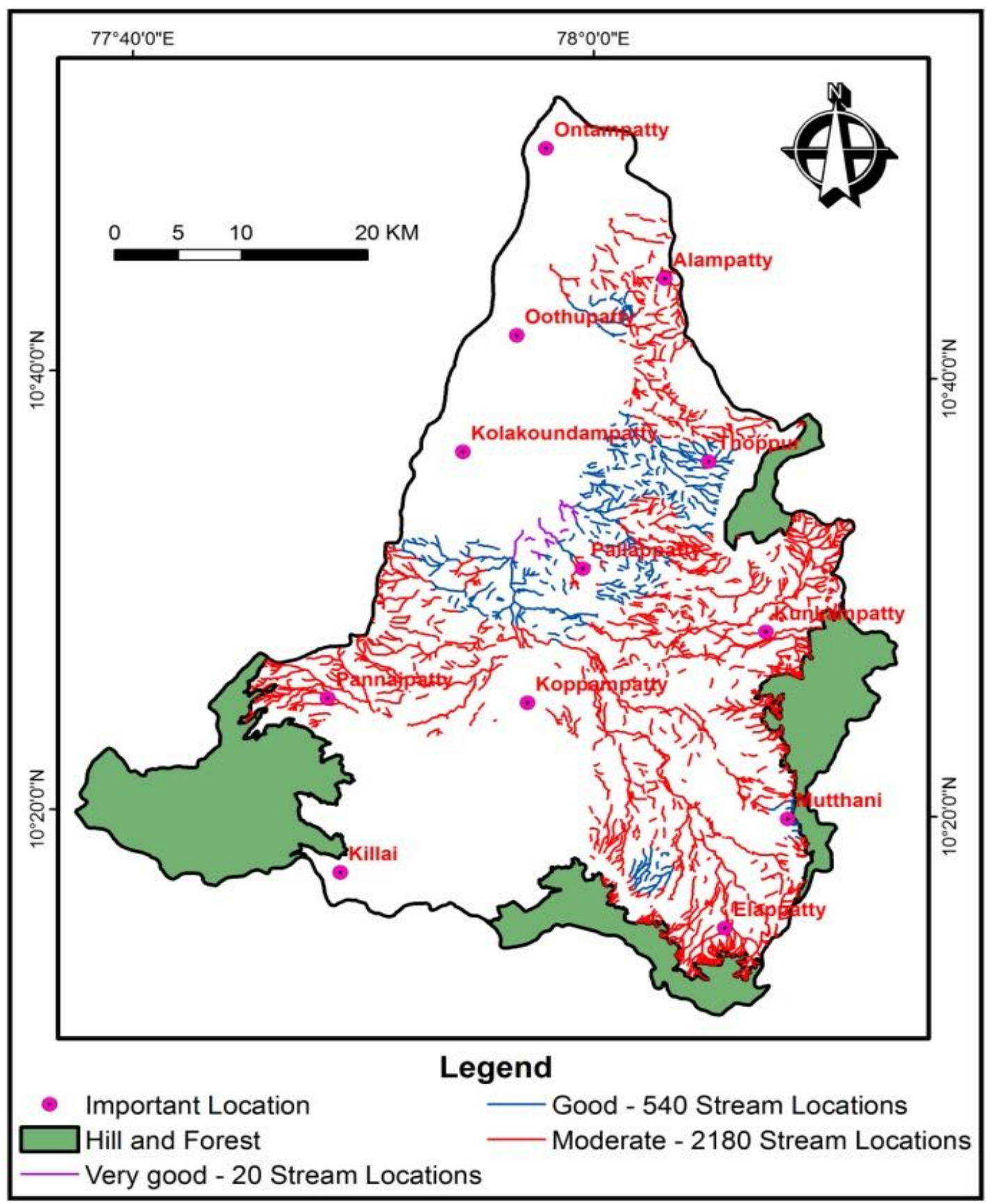

Figure 9 Suitable Sites for Artificial recharge location based on Sub surface dyke Method 
Table 8. GIS Output - Subsurface dyke - Number of streams with its class

\begin{tabular}{|c|c|c|}
\hline Sl. No. & Class & No. of streams \\
\hline 1 & Very good & 20 \\
\hline 2 & Good & 540 \\
\hline 3 & Moderate & 2180 \\
\hline
\end{tabular}

\subsection{Site selection for check dams}

Check dams are small barriers built across small streams. It can be constructed in both hard rock and alluvial formations. The potential site for check dam should be a gently sloping stream underlained by permeable or weathered rock so that the entrapped water can seep through the layers and replenish the nearby groundwater reserves and wells.

The following criteria were fixed for check dam site selection;

1. Slope (Slope $5^{\circ}$ - Good, Slope $10^{\circ}$ - Medium, Slope More than $20^{\circ}$ - Not suitable),

2. Top soil thickness, weathered zone thickness and fractured zone thickness (Medium to high is suitable),

3. Land use (Irrigation land) and

4. $\mathrm{pH}$ of water (not less than 6.5 and More than 8.5 is preferable)

Table 9 Assigned weightages for GIS analysis - Check dam

\begin{tabular}{|c|c|c|c|c|}
\hline \multirow{2}{*}{$\begin{array}{c}\text { Sl. } \\
\text { No. }\end{array}$} & \multirow{2}{*}{ Criteria } & \multicolumn{3}{|c|}{ Classes } \\
\cline { 3 - 5 } & Plope & $1\left(\right.$ Slope $\left.>10^{\circ}\right)$ & $2\left(\right.$ Slope $\left.5^{\circ}-10^{\circ}\right)$ & $3\left(\right.$ Slope $\left.0^{\circ}-5^{\circ}\right)$ \\
\hline 1 & $\begin{array}{c}\text { Aquifer } \\
\text { thickness }\end{array}$ & $1(<26.61 \mathrm{~m})$ & $2(26.61 \mathrm{~m}-166.83 \mathrm{~m})$ & $3(>166.83 \mathrm{~m})$ \\
\hline 2 & Land use & 0 & 0 & 2 (Irrigation land) \\
\hline 4 & $\mathrm{pH}$ & 0 & 0 & $\begin{array}{c}\text { (pH Less than } 6.5 \text { and more } \\
\text { than } 8.5)\end{array}$ \\
\hline
\end{tabular}

Concerning the above mentioned criteria, maps were taken for an overlay analysis with proper weightage index using GIS. The weightage index and GIS analysis are given in Table 9 and Table 10. The final GIS results and outputs are given in Table 11. The definite integration map arrived after GIS analysis is shown in Figure 10. The GIS output indicates that about 2019 locations are favorable for the construction of check dams. About 25 out of 2019 stream sites are most suitable for creation of this type of artificial recharge structure. The output further shows that about 379 locations fall in good category and 1615 locations represent the moderate 
Vol. 2 Iss. 2 Year 2020

D. Karunanidhi et al.,/ 2020

categories for the construction of check dams to augment groundwater resources in the Subbasin.

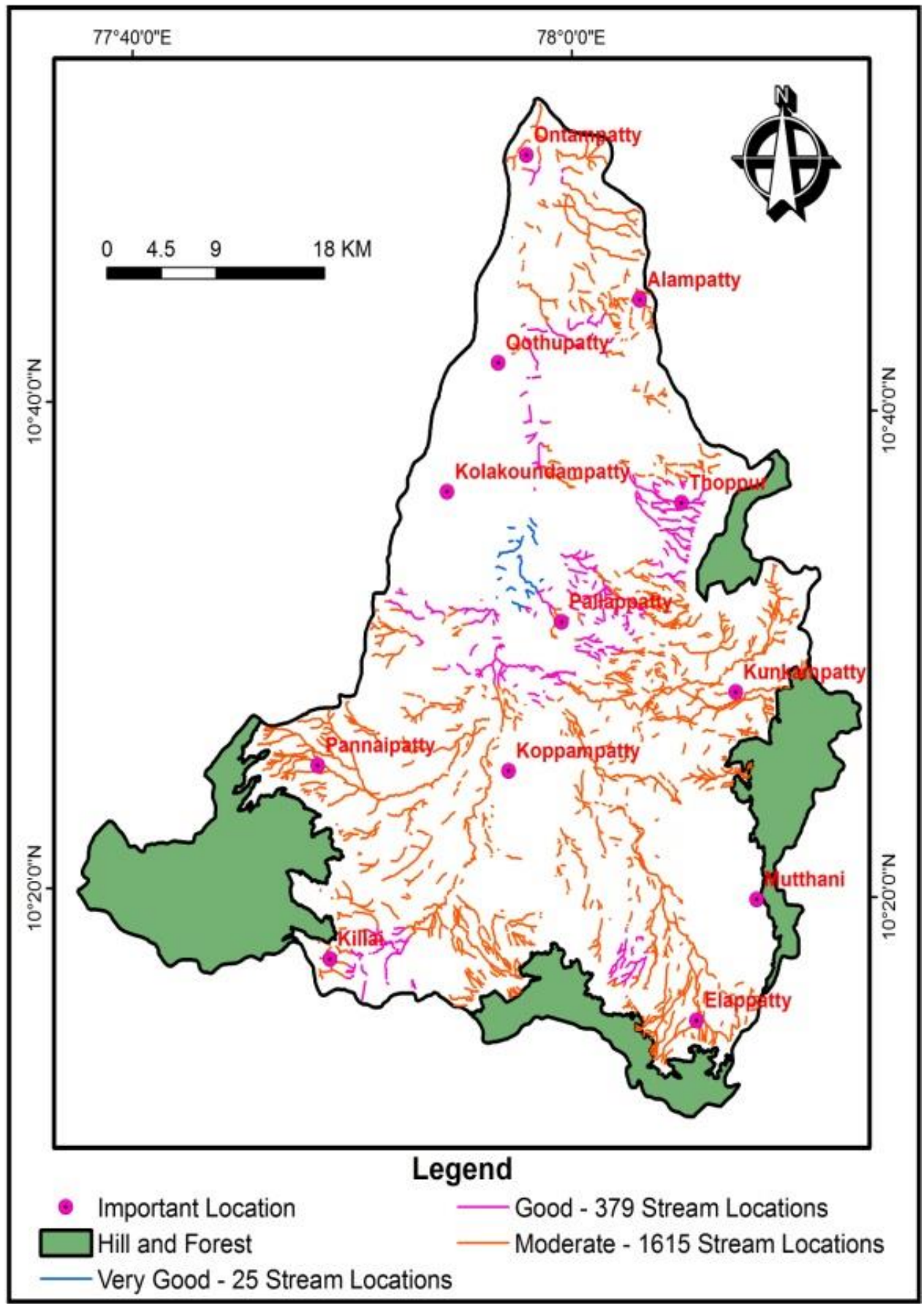

Figure 10 Suitable Sites for Artificial recharge location based on Check Dam Method 
Table 10. GIS overlay analysis - Check da

\begin{tabular}{|c|c|c|c|c|}
\hline Sl. No. & \multicolumn{2}{|c|}{ Maps Used } & GIS Analysis - Operation & Result Map \\
\hline 1 & Drainage & slope & Intersect & Map- 1 \\
\hline 2 & Map 1 & Aquifer thickness & Union & Map - 2 \\
\hline 3 & Map 2 & Land use & Union & Map - 3 \\
\hline 4 & Map 3 & pH & Union & Map - 4 \\
\hline 5 & Map 4 & Drainage & Intersect & Final map \\
\hline
\end{tabular}

Table 11. GIS Result - Check dam method - Number of streams with its class

\begin{tabular}{|c|c|c|c|}
\hline Sl. No. & Class & No. of streams & No. of Villages \\
\hline 1 & Very Good & 25 & 7 \\
\hline 2 & Good & 379 & 51 \\
\hline 3 & Moderate & 1615 & 133 \\
\hline
\end{tabular}

\section{Conclusion}

GIS is a useful tool for groundwater studies, as it has the capability to store and manipulate a vast array of data. To determine the artificial recharge sites for construction of check dams and subsurface dykes, the multilayered approach was essential which in turn culminated in the multi-criteria analysis in GIS and to formulate the required weighted aggregation in the Kadavanar Sub-basin, Tamil Nadu, India for augmentation of groundwater resources. Geophysical survey (vertical electrical sounding) was conducted at 50 locations in the Sub-basin to map the aquifer thickness. Different thematic layers perceived through GIS needed to map the feasible groundwater recharge locations across the streams viz. hydrological, rainfall, groundwater level, Kadavanar Sub-basin drainage, aquifer thickness, slope and land use/land cover, were incorporated into maps and geo-referenced. The various classifications based on weightage represent the right locations for suitable groundwater recharge sites on the map. These locations assume greater importance to bring about a wider tapping of the otherwise mere surface runoff to the effective cause the artificial groundwater recharge. This is an integrated approach towards groundwater recharge and a wholesome water resource management. The present study confines to judicious identification and integration of parameters contributing towards ground water recharge site suitability identification and integration with site reality. This process can be adapted to identify water starved areas where there is growing concern with regular depletion of groundwater so that artificial recharge methods could be employed and with slight modifications to suit the site conditions. 


\section{References}

[1] H. N. Varma, K. N. Tiwari, (1995) Current status and prospectus of rainwater harvesting, Indian National Committee on Hydrology (INCOH), National Institute of Hydrology, Roorkee, India.

[2] M. R. Shankar, G. Mohan, A GIS based hydro geomorphic approach for identification of site-specific artificial-recharge techniques in the Deccan Volcanic Province, Journal of Earth System Science, 114 (2005) 505-514.

[3] S. Anbazhagan, S. M. Ramasamy, S. D. Gupta, Remote sensing and GIS for artificial recharge study, runoff estimation and planning in Ayyar basin, Tamil Nadu, India, Environmental Geology, 48 (2005) 158-170.

[4] S. Shahid, S. Nath, J. Roy, Groundwater potential modelling in a soft rock area using a GIS, International Journal of Remote Sensing, 21(2000) 1919-1924.

[5] E. Sener, A. Davraz, M. Ozcelik, An integration of GIS and remote sensing in groundwater investigations: a case study in Burdur, Turkey, Hydrogeology Journal, 13 (2005) 826-834.

[6] S. Kaliraj, N. Chandrasekar, N. S. Magesh, Identification of potential groundwater recharge zones in Vaigai upper basin, Tamil Nadu, using GIS-based analytical hierarchical process (AHP) technique, Arabian Journal of Geosciences, 7 (2014) 1385-1401.

[7] J. Szilagyi, F. E. Harvey, J. F. Ayers, Regional estimation of base recharge to ground water using water balance and a base-flow index, Ground Water, 41 (2003) 504-513.

[8] D. Koussis, E. Georgopoulou, A. Kotronarou, D. P. Lalas, P. Restrepo, G. Destouni, A. Gomez-Gotor, Cost-efficient management of coastal aquifers via recharge with treated wastewater and desalination of brackish groundwater: general framework, Hydrological Sciences Journal, 55 (2010) 1217-1233.

[9] D. Ramakrishnan, A. Bandyopadhyay, K. N. Kusuma, SCS-CN and GIS-based approach for identifying potential water harvesting sites in the Kali Watershed, Mahi River Basin, India, Journal of earth system science, 118 (2009) 355-368.

[10] Pandey, V. M. Chowdary, B. C. Mal, P. P. Dabral, Remote sensing and GIS for identification of suitable sites for soil and water conservation structures, Land Degradation \& Development, 22 (2011) 359-372.

[11] K. Saraf, P. R. Choudhury, Integrated remote sensing and GIS for groundwater exploration and identification of artificial recharge sites, International journal of Remote sensing, 19 (1998) 1825-1841.

[12] J. Krishnamurthy, A. Mani, V. Jayaraman, M. Manivel, Groundwater resources development in hard rock terrain-an approach using remote sensing and GIS techniques, International Journal of Applied Earth Observation and Geoinformation, 2 (2000) 204-215. 
[13] K. Agarwal, R. Mohan, S. K. S. Yadav, An integrated approach of remote sensing, GIS and geophysical techniques for hydrological studies in Rajpura block, Budaun district, Uttar Pradesh, Indian Journal of Power and River Valley Development, 54 (2004) 35-40.

\section{Acknowledgements: NIL}

Conflict of interest: NIL

About The License: (c) 2020 The Authors. This work is licensed under a Creative Commons Attribution 4.0 International License which permits unrestricted use, provided the original author and source are credited. 